\title{
QUALITY ASSESSMENT OF GIANT FRESHWATER PRAWN (Macrobrachium rosenbergii) IN ICE STORAGE CONDITION COLLECTED FROM SELECTED FARMS AND DEPOTS
}

\author{
M. N. Haider*, M. Faridullah, M. S. Reza, M. F. Hossain, M. Kamal \\ and M. N. Islam \\ Department of Fisheries Technology, Bangladesh Agricultural University \\ Mymensingh-2202, Bangladesh
}

\begin{abstract}
This study was conducted to evaluate the quality changes in an important crustacean species giant freshwater prawn, Macrobrachium rosenbergii (locally called golda) at various stages of handling. The samples under study were obtained from farms and depots of four golda producing districts viz. Khulna, Bagerhat, Jessore and Norial area by determining organoleptic and biochemical aspects. The golda samples stored in ice immediately after harvest were in acceptable condition for seven days after harvesting period while the samples obtained from depots from all stations were in acceptable condition for 4 days only. There was a large fall of protein solubility and ATPase activity in all the samples obtained from farms and depots. The fall of solubility and ATPase activity was faster in samples obtained from depots compared to the samples obtained from farm immediately after harvest. The large fall of protein solubility and ATPase activity of samples indicated the denaturation of protein during ice storage.
\end{abstract}

Key Words: Quality assessment, Macrobrachium rosenbergii, Ice storage, Protein solubility, ATPase activity

\section{INTRODUCTION}

Freshwater prawn, golda (Macrobrachium rosenbergii) is the largest one among the freshwater prawns and is preferred by the consumers at home and abroad for its taste, size and color. Bangladesh is a major exporter of $M$. rosenbergii caught from natural sources but with the increasing demand in the international market, golda farming has been expanding rapidly throughout the country. Over the recent past, there has been a notable increase in the export prices of the Bangladeshi prawn particularly in USA, Japan, and European markets (Ahmed, 2001).

Shellfish muscle is known to contain higher percentage of sarcoplasmic and myofibrillar protein and lower amount of stroma protein, higher percentage of unsaturated fatty acids that are degraded quickly through autolytic, microbial and oxidative spoilage.

*Corresponding author: raselmnh@yahoo.com 
Assessing and selecting for quality of prawn is of great importance to produce a level of quality which will satisfy both the customer and statutory food legislation. Over the years, many different methods of quality assessment have been developed and investigated in an attempt to determine the most suitable index for use in quality control testing. It has been stated frequently that no single method is generally reliable for assessment of freshness and spoilage in seafood. Nevertheless, numerous microbiological, chemical, biochemical, as well as other instrumental methods, are appropriate for this purpose as long as their range of applicability in terms of raw material, preserving parameters, and storage conditions are realized and respected. The objectives of this study were to evaluate the quality changes of $M$. resenbergii collected from different stations through sensory and biochemical techniques.

\section{MATERIALS AND METHODS}

M. rosenbergii samples were collected from selected farms and depots of Dumuria of Khulna, Bagerhat Sadar of Bagerhat, Avoynagar of Jessore and Kalia of Norail. The samples were transported to the laboratory of Department of Fisheries Technology, Bangladesh Agricultural University, Mymensingh in iced condition in an insulated box to assess the degree of freshness by organoleptic and biochemical methods.

\section{Organoleptic assessment}

For organoleptic quality assessment of Golda on the basis of odor, texture, colour (with shell), colour of flesh and general appearance of prawn, a five member panel was constituted. The panel members included Faculty members of the Faculty of Fisheries, Bangladesh Agricultural University, Mymensingh. Qualities of the collected prawns were assessed by using the descriptive scheme provided by Howgate et al. (1992). The guidelines used to assess the quality are given in Table 1.

Each attribute is scored from 1 to 5 (typically) by novice or experienced assessors with high score 25 indicating the best quality (excellent), 24-22 = very good, 21-19= good, 18-14 $=$ acceptable, $13-08=$ bad and 7-5 = very bad. The sum of all attribute scores is called demerit points, or grade points, and this value decrease linearly with storage time in ice. The direct relationship between grade point scores and storage time makes it easy to calculate remaining shelf life of fresh prawn when stored at $0^{\circ} \mathrm{C}$ (in ice).

\section{Biochemical Assessment}

\section{Measurement of $\mathrm{pH}$}

Two grams of peeled prawn sample was homogenized with $10 \mathrm{ml}$ distilled water in a blender and the $\mathrm{pH}$ was measured using a $\mathrm{pH}$ meter (Corning Model 250) for 30-60 seconds.

\section{Total volatile base nitrogen (TVB-N) determination}

Total volatile basic nitrogen (TVB-N) of the samples was determined according to the method described by the Official Journal of the European Communities (EC, 1995). Briefly, 
the procedure is as follows: exactly 10 gm of the ground prawn sample were weighed in a suitable container and mixed with $90 \mathrm{ml}$ of $6 \%$ perchloric acid. The samples were homogenized for two minutes with a blender. This was done in cool condition $\left(2-6^{\circ} \mathrm{C}\right)$.

Hundred $\mathrm{ml}$ of the extract was put in Kjeldahl flask and $20 \mathrm{ml}$ of $20 \%$ sodium hydroxide $(\mathrm{NaOH})$ solution and few glass beads were added in the flask. The distillate was fixed up in a conical flask with $50 \mathrm{ml} \mathrm{3 \%}$ boric acid solution containing 1-2 drops of mixed indicator. After boiling the flask for 15-20 minutes the distillate accumulated in conical flask which was titrated with $0.01 \mathrm{~N}$ hydrochloric acid $(\mathrm{HCl})$. The TVB-N is calculated by the following formula:

TVB-N $(\mathrm{mg} / 100 \mathrm{~g}$ samples $)=\frac{\mathrm{ml} \text {. of titrant } \times 0.14 \times 2 \times 100}{\text { Sample weight }}$

Table 1. Determination of the grade points or defect points

\begin{tabular}{l|lc}
\hline Characteristics of whole prawn & \multicolumn{1}{c}{ Defect characteristics } & Defect points \\
\hline A. Odour & Natural odour & 5 \\
& Neutral odour & 4 \\
& Slight sour odour & 3 \\
& Ammonical odour & 2 \\
& Rotten odour & 1 \\
\hline B. Colour (with shellon) & Natural colour & 5 \\
& Slight discolour/ slight pinkish & 4 \\
& Brownish red & 3 \\
& Discolour & 1 \\
\hline C. Colour of flesh & White colour of fresh prawn & 5 \\
& Slight pink colour & 4 \\
& Pink colour & 3 \\
& Dull/discolour & 1 \\
\hline D. Texture & Firm, consistent and elastic & 5 \\
& Moderately soft and some loss of elasticity & 4 \\
& Some softening & 3 \\
& Soft and Watery & 2 \\
& Flesh with juice & 1 \\
\hline E. General appearance & Bright shining and iridescent & 5 \\
& Slight dullness and loss of brightness & 4 \\
& Definite dullness and loss of brightness & 2 \\
& Dull & 1 \\
\hline
\end{tabular}

\section{Determination of solubility and ATPase activity from myofibrils}

Myofibrils were prepared from muscles immediately after excision according to Perry and Grey (1956) with slight modification. The muscle was chopped by a meat grinder and chilled minced muscle $(50 \mathrm{~g})$ was homogenized for $1 \mathrm{~min}$ in 5 volumes of $39 \mathrm{mM}$ borate 
buffer (pH 7.1) containing $25 \mathrm{mM} \mathrm{KCl}$ and $0.1 \mathrm{mM}$ DTT. The homogenate was centrifuged for $15 \mathrm{~min}$ at $600 \mathrm{x}$ g. The residue obtained was again homogenized and centrifuged for 15 $\mathrm{min}$. The light-colored upper layer of the residue consists of myofibril was recovered with small volume of $39 \mathrm{mM}$ borate buffer $(\mathrm{pH} 7.1)$ containing $0.1 \mathrm{M} \mathrm{KCl}$ and $0.1 \mathrm{mM}$ DTT. The suspension was centrifuged for $15 \mathrm{~min}$ to remove the supernatant. Myofibrils were diluted with 4 volumes of $39 \mathrm{mM}$ borate buffer ( $\mathrm{pH} 7.1$ ) containing $0.1 \mathrm{M} \mathrm{KCl}$ and $0.1 \mathrm{mM} \mathrm{DTT}$, and coarse materials were removed by centrifuging at $400 \times \mathrm{g}$. The suspension was centrifuged again for 15 mins. at $600 \times \mathrm{g}$ to precipitate the myofibril myofibril. After washing the pellet three times in the same way, myofibrils were suspended with a desired volume of $39 \mathrm{mM}$ borate buffer $(\mathrm{pH} 7.1)$ containing $0.1 \mathrm{M} \mathrm{KCl}$ to make a concentration of $10-15 \mathrm{mg} / \mathrm{ml}$. Then myofibrillar proteins were extracted from isolated myofibrils with $0.6 \mathrm{M} \mathrm{KCl}-0.03 \mathrm{M}$ Tris- $\mathrm{HCl}$ at $\mathrm{pH} 7.5$. The suspension was stirred gently and kept over night at $4{ }^{\circ} \mathrm{C}$. Then the solution was centrifuged at $900 \times \mathrm{g}$ for $30 \mathrm{~min}$ and protein content in the supernatant was determined by the Biuret method (Gornall et al., 1949).

\section{Assay of specific ATPase activity}

In this study $\mathrm{Ca}^{2+}$ - ATPase assay was determined. The reaction mixture for the $\mathrm{Ca}^{2+}$ ATPase assay contained $25 \mathrm{mM}$ Tris, $5 \mathrm{mM} \mathrm{CaCl}_{2}, 0.1 \mathrm{M}$ or $0.5 \mathrm{M} \mathrm{KCl}$ and $0.25 \mathrm{mg}$ myofibril per ml. After preparation of the reaction mixture, an appropriate quantity of myofibril suspension was pipetted to the reaction mixture followed by 2 mins. pre-incubation. The reaction was started by the addition of $1 \mathrm{mM}$ ATP and then $2 \mathrm{ml}$ portion of the reaction mixture was withdrawn at different time intervals. To stop the reaction $1 \mathrm{ml}$ of $15 \%$ trichloro-acetic acid was added. The supernatant obtained by $5 \mathrm{~min}$ centrifugation at $3000 \times \mathrm{g}$ was analyzed for the liberation of inorganic phosphate (Pi) by a method described by Fiske and Subba Row (1925).

\section{RESULTS AND DISCUSSION}

\section{Organoleptic Assessment}

The organoleptic characteristics are judged by 5 member panel test. The prawns those were collected from the farms were analyzed and assessed every alternate days and those from depots assessed every days to determine the grade points and quality status.

Total grade points to the samples those were stored in ice at farm level immediately after harvesting was $25,21,17,14$ and 11 on $1^{\text {st }}, 3^{\text {rd }}, 5^{\text {th }}, 7^{\text {th }}$ and $9^{\text {th }}$ day respectively. Sample was excellent in quality, at the $3^{\text {rd }}$ day the samples was good and on $5^{\text {th }}$ and $7^{\text {th }}$ days the quality deteriorate some what but was in acceptable condition. On the $9^{\text {th }}$ day the quality was found completely deteriorated and crossed the point of rejection. Thus, the samples collected from the farm were in acceptable condition up to seven days. The samples obtained from depots were found in acceptable condition for four days only. Total grade points on $1^{\text {st }}, 2^{\text {nd }}, 3^{\text {rd }}, 4^{\text {th }}$ and $5^{\text {th }}$ day was $23,19,16,14$ and nine respectively. At the $5^{\text {th }}$ day of observation the samples were unacceptable as a result of spoilage. From this assessment it is obvious that the quality losses of prawns occurred at various stages due to rough handling and delay in icing after harvest. 


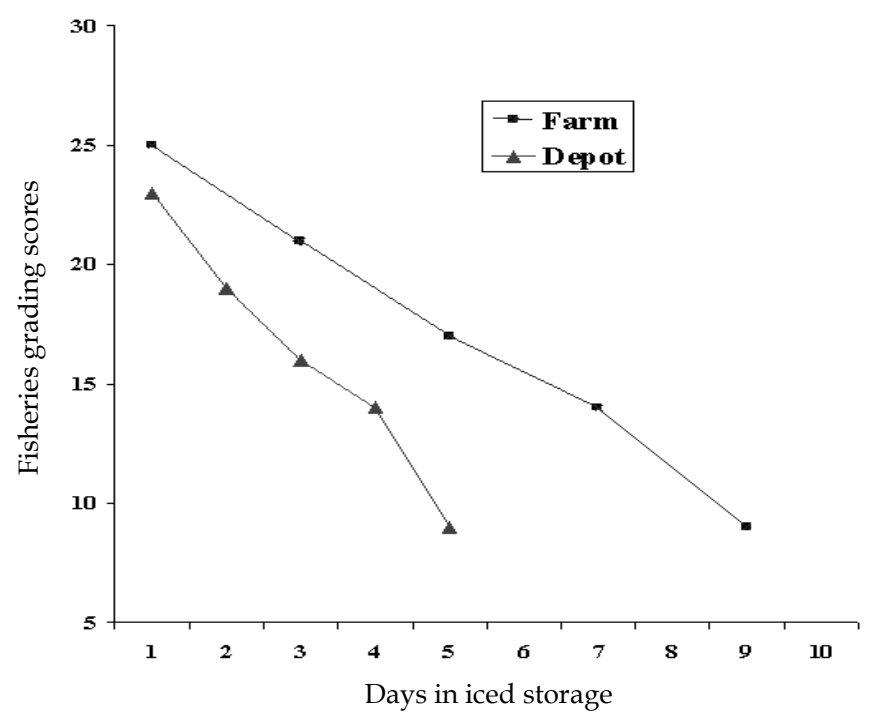

Fig. 1. Mean differences of the degree of Freshness of M. rosenbergii collected from different farms and depots

The pattern of organoleptic quality changes of prawn of farms can be roughly divided in to four phases corresponding to the periods of 0 to 1,2 to 4,5 to 7 and 8 to 9 days in ice. In phase I, the prawns were in very good condition with fresh bright shining and iridescent appearance, firm consistent and elastic texture, characteristics of white colour and natural shell odour and colour. In phase II, there was slight dullness and loss of brightness, slightly softening and some loss of texture, color of flesh and shell turned into slight pink and neutral odour. In phase III, there was considerable loss of brightness and softening of texture. The flesh was neutral but had no off odour. In phase IV, there was sign of early spoilage with sour odour and the shell became discolored. In the latter part of this phase, the prawn began to taste stale and its appearance began to show obvious signs of spoilage and had unpleasant smell.

Literatures are available about the oraganoleptic quality assessment suggestingat the shelf-life of prawn during ice storage which from species to species, due to factors like chemical composition, ambient temperature in which they are kept, post harvest handling and icing (Barlie et al., 1985; Reilly et al., 1985; Dawood et al., 1986; Shamshad et al., 1990; Fonseka and Ranjini, 1994; Kodoria and Rojas, 1996; Rahman et al., 2001a and Rahman et al., 2001b). Shelf-life of shrimp ranged from 7 hours at $35^{\circ} \mathrm{C}$ to 13 days at $0^{\circ} \mathrm{C}$ (Shamshad et al., 1990). At ambient temperature shrimps were rejected after 12 hours while the shrimp held in ice were rejected after 15 days storage (Fonseka and Ranjini, 1994). In the present study sensory evaluation indicated that raw prawns of the farm had excellent freshness during the first three days of ice storage and was in acceptable condition for up to seven days which is more or less similar to the results obtained by Rahman et al., (2001b). They reported that prawn those kept in ice immediately after harvesting remain in acceptable 
condition for seven days. In another study they (Rahman, et al., 2001a) determined the quality changes of prawn in ice and found that head-on prawns remain in acceptable condition in terms of commercial standard for up to 6 days, while headless ones for seven days.

The samples obtained from the depot were found acceptable for up to 4 days only. This shortened shelf-life may due to improper and delay icing of the prawn before transporting to the depots. Because Rahman et al. (2001b) found that the farms do not have sufficient facilities of immediate icing of the catch and therefore remain at ambient temperature for 4 to 12 hours prior to icing whereas delaying of 4,8 , and 12 hours in icing shortened the shelf life to 3,2 , and 1 days, respectively.

\section{Biochemical Assessment}

\section{$\mathrm{pH}$ of the ice stored samples}

Studies were conducted with $M$. rosenbergii obtained from culture farm and depot. The initial $\mathrm{pH}$ value of prawn sample from farm and depot were 6.8 and 6.5 respectively which gradually increased with the lapse of storage period. The $\mathrm{pH}$ value of the samples obtained from farm reached slightly beyond acceptable level after 6 days of storage. On the other hand, the samples obtained from depot were acceptable for up to 4 days in ice and during this period the $\mathrm{pH}$ value reached to 7.38 which are beyond the acceptable limit of 7.25. The decline in $\mathrm{pH}$ in early post-mortem muscle is due to the gradual hydrolysis during the first few hours of glycogen to lactic acid. The decline in $\mathrm{pH}$ is also accompanied by the natural post-mortem stiffening called rigor-mortis (Fig. 2).

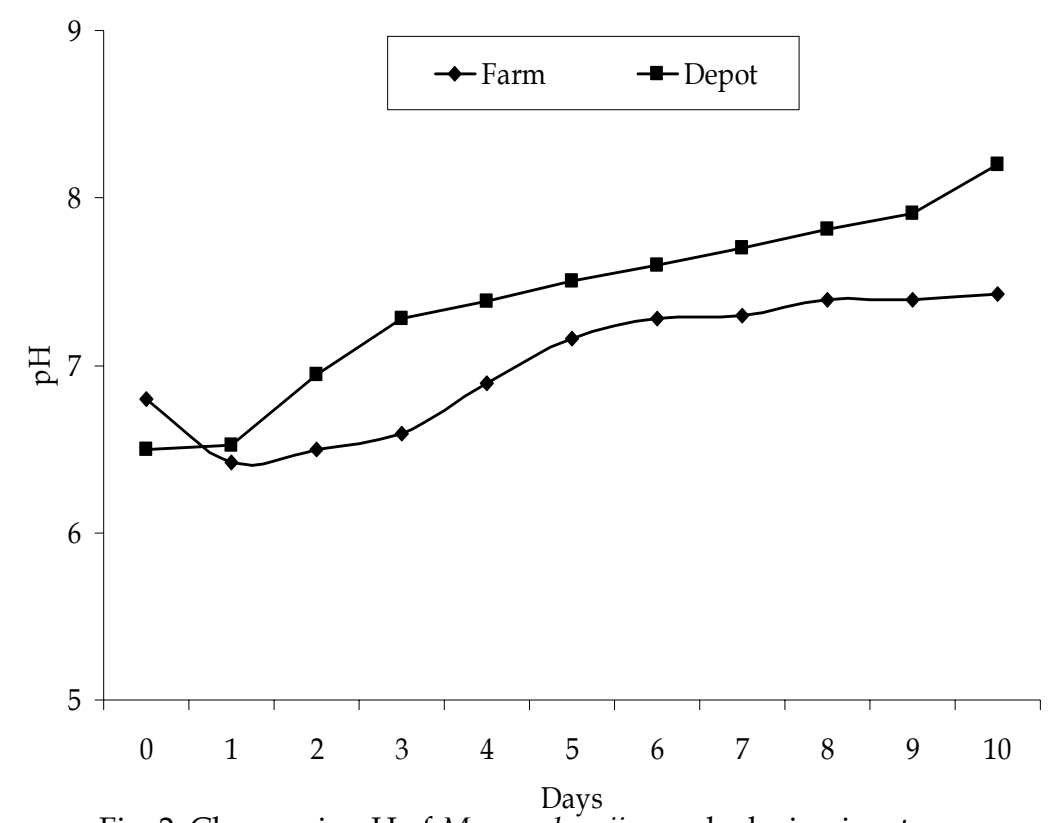

Fig. 2. Changes in $\mathrm{pH}$ of $M$. rosenbergii muscle during ice storage 
Available reports suggested that increase in $\mathrm{pH}$ value of the collected samples during ice storage is due to accumulation of some basic nitrogenous substances like TMA and ammonia by the action of enzymes and microorganisms. Rahman et al. (2001b) reported that the $\mathrm{pH}$ of prawn over the period increase gradually from 6.36 immediately after catch to 8.0 after 10 days of storage in ice. This indicated a similarity to the result of the present study.

\section{TVB-N of the ice stored samples}

The mean initial TVB-N values of the samples collected from farms and depots were 5.8 and $6.2 \mathrm{mg} / 100 \mathrm{~g}$ respectively, which also continuously increased during the progress of storage. In the samples collected from the farm, TVB-N value reached upper limit of 25 $\mathrm{mg} / 100 \mathrm{~g}$ after 6 days of storage while in samples collected from depot, TVB-N value reached beyond upper limit after 4 days of storage. There was a close relationship between TVB-N values and $\mathrm{pH}$ values where both the values increased with storage period. Another important relationship was between TVB-N values and organoleptic assessment of Golda during ice storage. Total freshness score or demerit score of the organoleptic assessment inversely changed with the TVB-N values of the collected samples (Fig. 3).

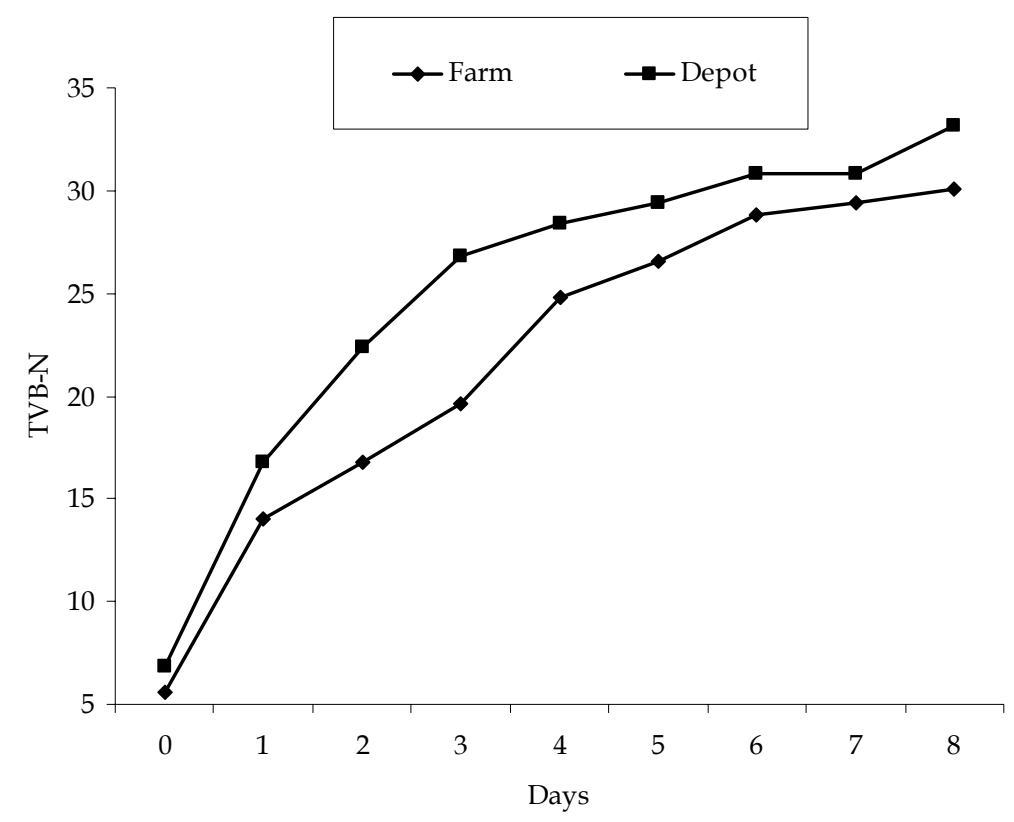

Fig. 3. Changes in TVB-N (mg/100g) values of $M$. rosenbergii muscle during ice storage

The available reports suggested that, the upper limit of $30 \mathrm{mg}$ TVB-N/100g is considered as acceptable for finfish such as cod, haddock, eel and sea pike. The values fluctuated during ambient temperature and subsequent storage in ice. The fluctuation levels of TVB$\mathrm{N}$ are probably due to the washing effects of ice during storage (Cobb et al., 1976). The TVB-N values of samples stored at $0^{\circ} \mathrm{C}$ were lower than the recommended limits $(30 \mathrm{mg}$ 
$\mathrm{N} / 100 \mathrm{~g}$ ), even after 10 days storage. However, in samples stored at $5^{\circ} \mathrm{C}$, this value found after 5 days (Leitao and Daniel, 2000).

The TVB-N values increased considerably with the storage period, and after 7 days, the TVB-N values were found within the recommended limit of $30 \mathrm{mg} / 100 \mathrm{~g}$ in iced stored prawn (Rahman et al., 2001b). This result revealed similarity to the result of the present study with the prawn samples collected from different farms of the country.

\section{Changes in the myofibrillar protein solubility during ice storage:}

The mean solubility and ATPase activities of the collected samples from different stations were also assessed to determine the degree of denaturation or degradation of the myofibrillar protein in ice storage condition. Studies conducted with the ice-stored $M$. rosenbergii showed that the mean initial myofibrillar protein solubility of the farm samples was $87 \%$, which decreased to $53 \%$ during 10 days of ice storage. Similarly initial myofibrillar protein solubility of samples obtained from depot was $77 \%$ which also declined to $43 \%$ after 10 days of storage. The present study indicated that the protein solubility falls with the length of the storage period in ice storage condition. Moreover, the mean solubility was found significantly lower to the samples collected from depot rather than those from four farms. The decrease in the solubility of the protein may be the result of the proteolytic enzymes activity on the muscle protein (Fig. 4).

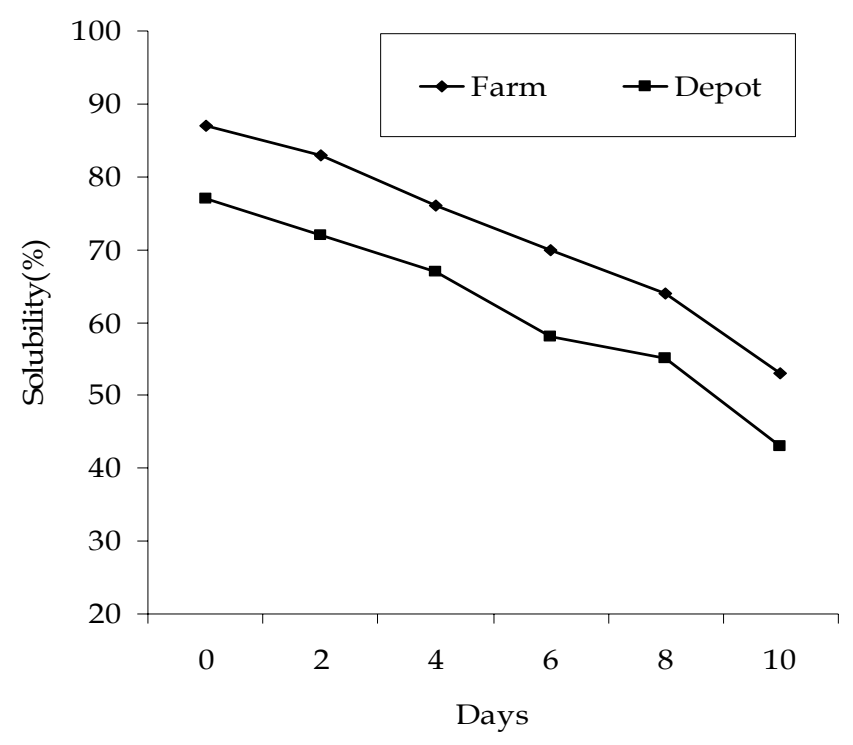

Fig. 4. Changes of Myofibrillar protein solubility of M. rosenbergii during ice storage

\section{ATPase activity during ice storage}

ATPase activity of the myofibrillar protein was determined in presence of $0.1 \mathrm{M} \mathrm{KCl}$ with the prawn samples collected from different samples of farms and depots. The mean $\mathrm{Ca}^{+2}$ ATPase activity of the myofibrillar protein was found to $0.482 \mu \mathrm{mol}-\mathrm{pi} / \mathrm{min}$. $\mathrm{mg}$ in the 
prawn collected from farms, which was found to decline sharply to $0.287 \mu \mathrm{mol}-\mathrm{pi} / \mathrm{min}$. $\mathrm{mg}$ at the end of the 10 days of iced storage condition. Initially the mean ATPase activity of the myofibrillar protein of the samples from depot was found more or less similar to the value obtained in the farm sample which was $0.426 \mu \mathrm{mol}-\mathrm{pi} / \mathrm{min}$. $\mathrm{mg}$ but it was found to decline rapidly during ice storage and at the end of the 8 days of ice storage condition the result was $0.254 \mu \mathrm{mol}-\mathrm{pi} / \mathrm{min} . / \mathrm{mg}$. Thus, the rapid loss of $\mathrm{Ca}^{+2} \mathrm{ATPase}$ activity was more in the samples collected from depot than those from farm. Reduction of the ATPase activity of the myofibrillar protein during ice storage occurs as a result of denaturation of protein (Fig. 5).

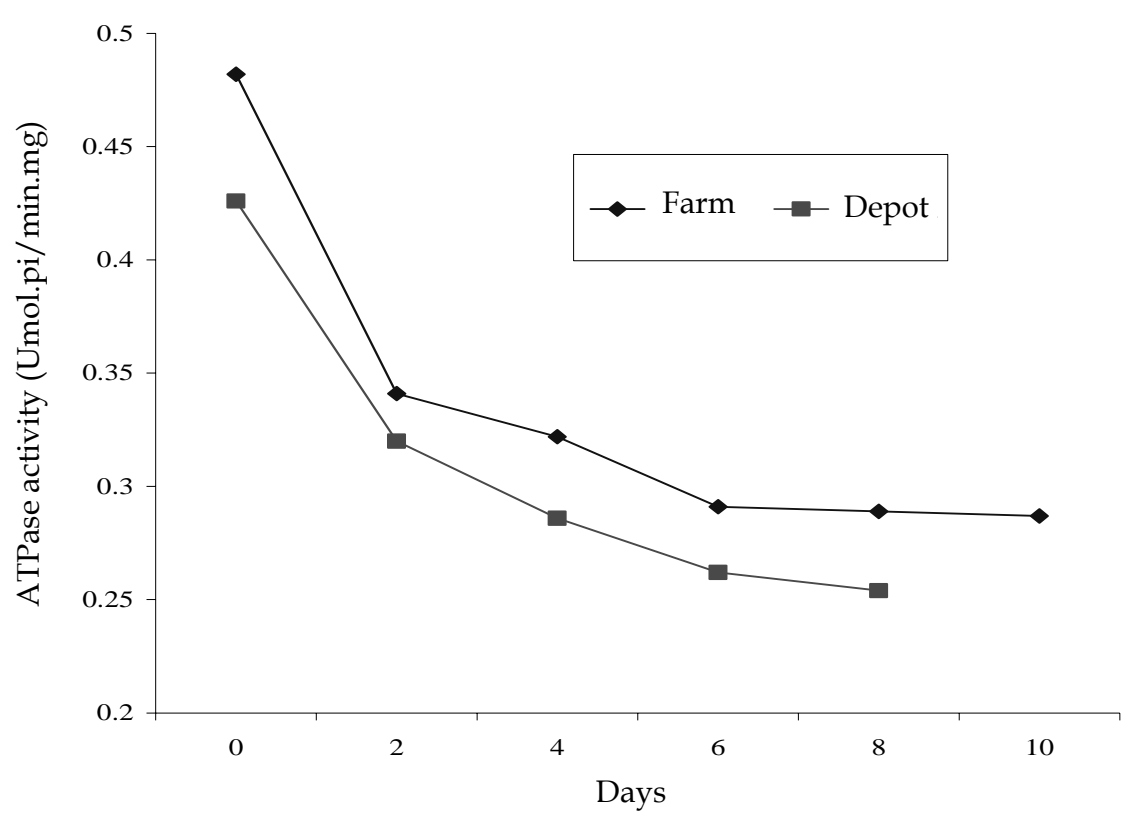

Fig. 5. Changes in mean ATPase activity of Myofibrollar Protein of M. rosenbergii obtained from samples of farms and depots

The results obtained from the present study are in agreement with those reported for various fish and shellfish species (Kamal et al., 1990; Yasmin et al., 2000; Rahman et al., 2001c). Yasmin et al. (2000) reported that myofibillar $\mathrm{Ca}^{2+}$-ATPase activities of catla in presence of $0.1 \mathrm{M} \mathrm{KCl}$ were remained unchanged upto the first 5 days of storage and then gradually decreased along with the storage period and at the end of the 20 days of storage the activity declined to about $40 \%$ of its initial level. On the other hand, there was little or no change of $\mathrm{Ca}^{+}$-ATPase activities of myofibrillar protein in the presence of $0.5 \mathrm{M} \mathrm{KCl}$ throughout the storage period. In a similar study, they also reported that in case of mrigal, the initial $\mathrm{Ca}^{2+}$-ATPase activities in the presence of $0.1 \mathrm{M} \mathrm{KCl}$ and $0.5 \mathrm{M} \mathrm{KCl}$ were 0.44 and $0.11 \mu \mathrm{mol}-\mathrm{pi} / \mathrm{min}$. mg respectively, which declined rapidly during 10 days of storage and after 20 days of storage, the activity decreased to 60 and $20 \%$ respectively. 
Rahman et al. (2001c) studied that the initial $\mathrm{Ca}^{2+}$ - ATPase activities of $M$. rosenbergii in presence of $0.1 \mathrm{M} \mathrm{KCl}$ was $0.46 \mu \mathrm{mol}-\mathrm{pi} / \mathrm{min}$. mg which slightly decreased to $0.35 \mu \mathrm{mol}-$ $\mathrm{pi} / \mathrm{min}$. mg after 10 days of storage, while there was little or no change in $\mathrm{Ca}^{2+}$ - ATPase activities in the presence of $0.5 \mathrm{M} \mathrm{KCl}$. On the other hand, the mean ATPase activity of the prawn obtained from different samples in the present study from farm was $0.482 \mu$ mol$\mathrm{pi} / \mathrm{min}$. $\mathrm{mg}$ and from depots $0.426 \mu \mathrm{mol}-\mathrm{pi} / \mathrm{min}$. $\mathrm{mg}$, which indicated no significant differences to the reported results.

Determination of quality assessment of $M$. rosenbergii by organoleptic and biochemical methods indicate that its shelf-life was higher in samples obtained from the farms than depots. This is an indication that considerable loss of quality during different stages of handling from farm to depot level. The government has already taken initiative through Department of Fisheries (DoF) to reduce such quality loss, which will be helpful to reduce such loss and simultaneously increase the market price beneficial for its producers.

\section{REFERENCES}

Ahmed, N. 2001. Socio-economic aspects of freshwater prawn culture development in Bangladesh. Ph. D. Thesis. University of Starling, UK. p. 320.

Barlie, L. E., Milla, A. D., Reilly and Villadesen, A. 1985. Spoilage Pattern of Mackerel (Rastrelliger funghni) 1. Delay in Icing. P. 29-40. In Reilly, A. (ed). Spoilage of Tropical Fish and Product Development. FAO Fishery Reports 317 Supp1, p. 474.

Cobb III, B. F., Vanderzant, C., Hanna, M. O. and Chia Ping S. Yeh. 1976. Effect of ice storage on microbiological and chemical changes in shrimp and melting ice in a model system. Journal of Food Science, 41(1976). p. 29.

Dawood, A. A., Roy, R. N. and Williams, C. S. 1986. Effect of Delayed Icing on the Storage Life of Rainbow trout. J. Food Technol., 21: 159-166.

European Communities (EC). 1995. Determination of the concentration of volatile nitrogenous bases (TVBN) in fish and fish products: A reference procedure. Official Journal of the European Communities. Commission Decision, p. 15.

Fiske, C. H. and SubbaRow, Y. 1925. The colometric determination of phosphorus. J. Biol. Chem., 66: 375-400.

Fonseka, T. S. G. and Ranjini, I. V. 1994. Storage life of pond cultured shrimp (Penaeus monodon) held in melting ice at ambient temperature, Annual Scientific Session, $2^{\text {nd }}$ November 1997, Nara, Srilanka. pp. 130-134.

Gornall, A. G., Bardawill, C. J. and David, M. M. 1949. Determination of serum proteins by means of the biuret reaction. J. Biol. Chem., 177: 751-766.

Kamal, M., Watabe, S. and Hashimoto. 1990. Stability of sardine myofibrils during storage at various pH values. Nippon Suisan Gakkaishi, 56: 83-90.

Kodoria, M. and Rojas M. 1996. Stability in ice of cultured prawns (Penaeus vannamei). Working paper in Latin America. Porlamar, Venezuela, 21-25 March 1996. 
Leitao, M. F. F. and Daniel P. A. R. 2000. Microbiological and Chemical Changes in Freshwater Prawn (Macrobrachium rosenbergii) Stored Under Refrigeration. Braz. J. Microbiol. Vol. 31 No. 3 SãoPaulo July/Sept. 2000.

Perry, S. V. and Grey, T. C. 1956. A study on the effect of substrate concentration and certain relaxing factors on the magnesium activated myofibrillar adenosine triphosphatase. Biochem. J., 64: 184-192.

Rahman, M., Yasmin, L., Kamal, M., Mazid, M. A. and Islam, M. N. 2001a. Effect of delayed icing on the quality changes in brackish water shrimp Penaeus monodon during ice storage. Pak. J. Biologl. Sci., 4(11): 1390-1394.

Rahman, M., Yasmin, L., Kamal, M., Kamruzzaman, M., Islam, M. N. and Ochiai, Y. $2001 b$. Effect of delayed icing on the quality changes in freshwater prawn Macrobrachium rosenbergii during subsequent storage. Bull. Fac. Edu. Ibaraki Univ. (Nat. Sci.), 50: 51-57.

Rahman, M., Yasmin, L., Kamal, M., Islam, M. N. and Ochiai, Y. 2001c. Quality changes in freshwater prawn M. rosenbergii during ice storage. Bull. Fac. Edu. Ibaraki Univ. (Nat. Sci.), 50: 39-49.

Reilly, A., Bernate, M. A. and Dangla, E. 1985. Quality changes in Brackish water prawns (Penaeus monodon) during storage at ambient temperature, in ice and after delays icing. In Reilly, A. (ed). Spoilage of Tropical Fish and Product Development. FAO Fishery Report 317 Suppl., pp. 474.

Shamsad, S. I., Nisa, K. U., Riaz, M., Zuberi, R. and Qadri, R. B. 1990. Shelf life of shrimp (Penaeus merguiensis) stored at different temperatures. J. Food Sci., 55: 1201.

Shewan, J. M., Machintosh, R. G., Tucker, C. G. and Ehrenberg, A. S. C. 1953. The development of a Numerical Scoring System for the Sensory Assessment of the Spoilage of Wet White Fish Stored in Ice. J. Sci. Food Agr., 4: 283-297.

Yasmin, L., Ahmed, K., Kamal, M. and Ochiai, Y. 2000. Changes in ATPase activity and solubility of myofibrillar proteins from Indian major carps during ice storage. Bull. Fac. Edu. Ibaraki Univ. (Nat. Sci.), 49: 131-137. 